\title{
Penentuan Kapasitas dan Lokasi Optimal dari Pembangkit Tersebar pada Jaringan Distribusi Penyulang Nila di Gardu Induk Metro
}

\author{
Awansah*, Osea Zebua dan Herri Gusmedi \\ Jurusan Teknik Elektro, Fakultas Teknik, Universitas Lampung \\ *Corresponding author, e-mail: awansah.st@gmail.com
}

\begin{abstract}
Abstrak - Penempatan pembangkit tersebar (DG) merupakan salah satu alternatif untuk mengurangi rugi-rugi daya pada jaringan distribusi. Namun penempatan DG dengan kapasitas dan lokasi yang tidak optimal dapat mempengaruhi profil tegangan dan stabilitas tegangan. Makalah ini bertujuan untuk menentukan kapasitas dan lokasi yang optimal dari DG untuk mengurangi rugi-rugi daya aktif dan memperbaiki profil tegangan serta indeks stabilitas tegangan. Simulasi dilakukan dengan menempatkan satu DG pada sistem IEEE 30 bus dan pada penyulang Nila di gardu induk Metro sebagai studi kasus jaringan distribusi. Dua tipe DG digunakan dalam simulasi ini, yakni DG yang hanya menyuplai daya aktif saja dan DG yang dapat menyuplai daya aktif dan reaktif. Perhitungan aliran daya dilakukan dengan menggunakan metode forward/backward sweep dan semua program ditulis dengan menggunakan perangkat lunak MATLAB. Hasil simulasi menunjukkan bahwa metode yang digunakan dapat menentukan kapasitas dan lokasi optimal dari masing-masing jenis DG untuk mengurangi rugi-rugi daya aktif secara optimal dan memperbaiki profil tegangan dan indeks stabilitas tegangan pada setiap bus di penyulang Nila.
\end{abstract}

Kata Kunci : Pembangkit tersebar, kapasitas dan lokasi optimal, jaringan distribusi, minimisasi rugi-rugi daya

\begin{abstract}
Installation of distributed generation (DG) is one alternatives to reduce power loss in distribution network. However, the placement of DG with non-optimal capacity and location may affect the voltage profile and voltage stability. This paper aims to find the optimal capacity and location of DG in order to reduce active power losses and improve the voltage profile and the voltage stability index. The simulation is performed by installing a DG on distribution network case studies i.e. IEEE 30 bus system and on the Nila feeder of Metro substation. Two types of DG are used for this simulation, i.e. DG that only produce active power and DG that produce both active and reactive power. Power flow calculations are performed using the forward/backward sweep method and all programming is written using MATLAB software. Simulation results show that the method can obtain the optimal capacity and location of DG. After installation the DGs, power losses, voltage profile and voltage stability index on each bus in Nila feeder have improved.
\end{abstract}

Keywords : Distributed generation,optimal capacity and location, distribution network, power loss minimization

\section{Pendahuluan}

Pertumbuhan beban yang besar semakin meningkatkan rugi-rugi daya aktif, menurunkan profil tegangan dan mengurangi stabilitas tegangan dari jaringan distribusi. Pembangkit tersebar (distributed generation/DG) menjadi salah satu alternatif untuk mengatasi masalahmasalah yang disebabkan kenaikan beban pada jaringan distribusi. Namun, pemasangan DG juga merubah kondisi operasi dan kontrol pada jaringan distribusi. Pemasangan DG dengan kapasitas dan lokasi penempatan yang tidak optimal dapat mengakibatkan rugi-rugi daya aktif yang semakin besar dan semakin mengurangi stabilitas tegangan [1].

Berbagai penelitian yang terdahulu telah mencari lokasi dan kapasitas DG pada jaringan distribusi dengan fungsi objektif adalah minimisasi rugi-rugi daya aktif total dengan perbaikan profil tegangan dan indeks stabilitas tegangan pada setiap bus [2, 3]. Berbagai metode optimisasi metaheuristik juga telah digunakan untuk mencari kapasitas dan lokasi optimal dari satu atau banyak DG, seperti Particle Swarm Optimization (PSO) [4], Algoritma Artificial Bee Colony (ABC) [5] dan Bacterial Foraging [6]. 
Metode analisis juga telah diusulkan oleh Hung dkk. [7] untuk mencari kapasitas dan lokasi optimal dari DG pada jaringan distribusi primer. Metode analisis ini dapat menentukan kapasitas dan lokasi optimal dari DG dengan berbagai faktor daya.

Makalah ini menyajikan metode analisis yang diusulkan oleh Hung dkk. untuk menentukan kapasitas dan lokasi optimal pembangkit tersebar (DG) untuk meminimisasi rugi-rugi daya aktif total sekaligus memperbaiki indeks stabilitas tegangan pada jaringan distribusi, dengan studi kasus penyulang Nila di Gardu Induk Metro Lampung. Studi kasus IEEE 30 bus juga digunakan sebagai perbandingan [8]. Perhitungan aliran daya menggunakan metode forward backward sweep.

\section{Tinjauan Pustaka}

\subsection{Aliran Daya Forward/Backward Sweep}

Metode perhitungan aliran daya Forward/Backward Sweep sangat efisien untuk jaringan distribusi radial karena rendahnya ketergantungan hubungan antar saluran [9]. Metode ini menggunakan hukum Kirchoff untuk tegangan dan arus. Metode ini terdiri dari dua tahap, yakni tahap backward sweep dan tahap forward sweep. Tahap backward sweep digunakan untuk menghitung arus pada setiap saluran dimulai dari bus akhir hingga bus sumber atau slack bus, yang dinyatakan dengan persamaan:

$$
I_{i}=\frac{P_{i}+j Q_{i}}{V_{i}}
$$

Tahap forward sweep digunakan untuk menghitung nilai tegangan pada setiap bus dengan menggunakan persamaan:

$$
V_{i}=V_{1}-I_{i}\left(R_{i}+j X_{i}\right)
$$

dimana: $I_{i}$ adalah arus beban pada bus $i, P_{i}+j Q_{i}$ adalah daya kompleks pada bus $i, R_{i}+j X_{i}$ adalah impedansi pada saluran $I, V_{1}$ adalah tegangan pada bus 1 dan $V_{i}$ adalah tegangan pada bus $i$. Untuk memudahkan perhitungan pada setiap iterasi digunakan matriks yang menghubungkan antara arus bus dengan arus saluran, yakni matriks BIBC (Bus Injection to Branch Current) dengan persamaan:

$$
[B]=[B I B C][I]
$$

dan matriks yang menghubungkan arus saluran dengan tegangan bus, yakni matriks BCBV (Branch Current to Bus Voltage), dengan persamaan:

$$
[\Delta V]=[B C B V][B]
$$

Substitusi persamaan 3 ke 4 diperoleh persamaan:

$$
[\Delta V]=[B C B V][B I B C][B]
$$

Tegangan pada setiap bus dapat dihitung dengan menggunakan persamaan:

$$
\left[V_{i}\right]=\left[V_{1}\right]-[\Delta V]
$$

\subsection{Pembangkit Tersebar}

Pembangkit tersebar (DG) adalah peralatan yang mampu menginjeksikan daya ke jaringan distribusi. DG dapat dikategorikan menjadi empat jenis berdasarkan kemampuan mengirimkan daya aktif atau daya reaktif [10], yakni:

1. Tipe 1: DG yang mampu menginjeksi hanya daya aktif saja. Contohnya: sel surya, mikroturbin dan sel bahan bakar.

2. Tipe 2: DG yang mampu menginjeksi hanya daya reaktif saja. Contohnya: kompensator sinkron gas turbin.

3. Tipe 3: DG yang mampu menginjeksikan baik daya aktif maupun daya reaktif. Contohnya, generator sinkron untuk coogeneration.

4. Tipe 4: DG yang mampu menginjeksikan daya aktif tetapi membutuhkan daya reaktif. Contohnya: generator induksi.

\subsection{Indeks Stabilitas Tegangan}

Indeks stabilitas tegangan (voltage stability index atau VSI) dari suatu bus pada sistem distribusi dapat dinyatakan dengan persamaan [11]:

$$
\begin{aligned}
V S I_{m 2}= & \left|V_{m 1}\right|^{4}-4\left(P_{m 2} x_{i}-\right. \\
& \left.Q_{m 2} r_{i}\right)^{2}-4\left(P_{m 2} r_{i}-\right. \\
& \left.Q_{m 2} x_{i}\right)\left|V_{m 2}\right|^{2}(7)
\end{aligned}
$$

dimana $V_{m 1}$ dan $V_{m 2}$ adalah tegangan pada bus $\mathrm{m} 1$ dan bus $\mathrm{m} 2, r_{i}$ dan $x_{i}$ adalah resistansi dan 
reaktansi dari saluran $i$ dan $P_{m 2}$ dan $Q_{m 2}$ adalah daya aktif dan daya reaktif pada bus $\mathrm{m} 2$.

Tegangan pada bus $\mathrm{m} 2$ dinyatakan stabil bila nilai VSI lebih besar dari nol dan sebaliknya jika nilai VSI lebih kecil dari nol, maka tegangan pada bus $\mathrm{m} 2$ tidak stabil.

\subsection{Penentuan Kapasitas dan Penempatan Optimal Pembangkit Tersebar Untuk Meminimisasi Rugi-rugi}

Rugi-rugi daya aktif total pada saluran biasanya dinyatakan dengan persamaan [10]:

$$
\begin{aligned}
P_{\text {loss }}= & \sum_{i=1}^{N} \sum_{j=1}^{N}\left[\alpha_{i j}\left(P_{i} P_{j}+Q_{i} Q_{j}\right)+\right. \\
& \left.\beta_{i j}\left(Q_{i} P_{j}-P_{i} Q_{j}\right)\right]
\end{aligned}
$$

dan

$$
\begin{aligned}
\alpha_{i j} & =\frac{r_{i j}}{V_{i} V_{j}} \cos \left(\delta_{i}-\delta_{j}\right) \\
\beta_{i j} & =\frac{r_{i j}}{V_{i} V_{j}} \sin \left(\delta_{i}-\delta_{j}\right)
\end{aligned}
$$

dimana $r_{i j}$ adalah resistansi saluran yang menghubungkan bus $i$ dan bus $j, P_{i}$ dan $Q_{i}$ adalah daya aktif dan daya reaktif pada bus $i, P_{j}$ dan $Q_{j}$ adalah daya aktif dan daya reaktif pada bus $j, V_{i}$ dan $V_{j}$ adalah tegangan pada bus $i$ dan bus $j$ serta $\delta_{i}$ dan $\delta_{j}$ adalah sudut tegangan pada bus $i$ dan bus $j$.

Misalkan $a=(\operatorname{sign})\left(\tan \left(\cos ^{-1} P F_{D G}\right)\right)$, daya reaktif yang dihasilkan oleh DG yang ditempatkan pada bus $i$ adalah:

$$
Q_{D G_{i}}=a P_{D G_{i}}
$$

dimana sign $=+1$ menyatakan DG menginjeksikan daya reaktif, sign $=-1$ menyatakan DG menyerap daya reaktif dan $P F_{D G}$ adalah faktor daya DG.

Daya aktif dan daya reaktif yang diinjeksikan dari bus $i$ adalah:

$$
\begin{aligned}
& P_{i}=P_{D G_{i}}-P_{D_{i}} \\
& Q_{i}=Q_{D G_{i}}-Q_{D_{i}}=a P_{D G_{i}}-Q_{D_{i}}
\end{aligned}
$$

Dengan substitusi persamaan (12) dan (13) ke persamaan (8), persamaaan rugi-rugi daya total

$$
\begin{aligned}
P_{\text {loss }}= & \sum_{i=1}^{N} \sum_{j=1}^{N}\left[\left[\alpha_{i j}\left(P_{D G_{i}}-P_{D_{i}}\right) P_{j}+\right.\right. \\
& \left.\left(a P_{D G_{i}}-Q_{D_{i}}\right) Q_{j}\right]+
\end{aligned}
$$

$$
\begin{aligned}
& \beta_{i j}\left[\left(a P_{D G_{i}}-Q_{D_{i}}\right) P_{j}-\right. \\
& \left.\left.\left(P_{D G_{i}}-P_{D_{i}}\right) Q_{j}\right]\right]
\end{aligned}
$$

Rugi-rugi daya aktif total paling minimum diperoleh jika,

$$
\begin{gathered}
\frac{\partial P_{\text {loss }}}{\partial P_{D G_{i}}}=2 \sum_{j=1}^{N}\left[\alpha_{i j}\left(P_{j}+a Q_{j}\right)+\right. \\
\left.\beta_{i j}\left(a P_{j}-Q_{j}\right)\right]=0
\end{gathered}
$$

Persamaan 14 dapat ditulis kembali menjadi:

$$
\begin{aligned}
& \alpha_{i i}\left(P_{i}+a Q_{i}\right)+\beta_{i i}\left(a P_{i}-Q_{i}\right)+ \\
& \sum_{\substack{j=1 \\
j \neq i}}^{N}\left(\alpha_{i j} P_{j}-\beta_{i j} Q_{j}\right)+a \sum_{\substack{j=1 \\
j \neq i}}^{N}\left(\alpha_{i j} Q_{j}+\right. \\
& \left.\beta_{i j} P_{j}\right)=0
\end{aligned}
$$

Dengan memasukkan persamaan (12) dan (13), persamaan (16) dapat ditulis sebagai,

$$
\begin{array}{r}
\alpha_{i i}\left(P_{D G_{i}}-P_{D_{i}}+a^{2} P_{D G_{i}}-a Q_{D_{i}}\right)+ \\
\beta_{i i}\left(a P_{D_{i}}-Q_{D_{i}}\right)+X_{i}+a Y_{i}=0
\end{array}
$$

dimana,

dan

$$
X_{i}=\sum_{\substack{j=1 \\ j \neq i}}^{N}\left(\alpha_{i j} P_{j}-\beta_{i j} Q_{j}\right)
$$

$$
Y_{i}=\sum_{\substack{j=1 \\ j \neq i}}^{N}\left(\alpha_{i j} Q_{j}+\beta_{i j} P_{j}\right)
$$

Kapasitas optimal dari DG pada setiap bus $i$ untuk meminimisasi rugi-rugi daya aktif total sesuai persamaan 17 adalah:

$$
P_{D G_{i}}=\frac{\alpha_{i i}\left(P_{D_{i}}+a Q_{D_{i}}\right)+\beta_{i i}\left(a P_{D_{i}}-Q_{D_{i}}\right)-X_{i}-a Y_{i}}{a^{2} \alpha_{i i}+\alpha_{i i}}
$$

Optimasi lokasi penempatan DG didasarkan atas persamaan (20), dimana kapasitas DG setiap bus dihitung. Bus dengan penempatan DG yang menghasilkan rugi-rugi daya aktif total yang paling minimum dipilih sebagai lokasi penempatan DG.

Optimasi kapasitas dan lokasi penempatan DG pada makalah ini dilakukan dengan fungsi objektif adalah rugi-rugi daya aktif minimum yang diberikan dengan persamaan (8), dengan batasan-batasan antara lain: 
1. DG tidak ditempatkan di bus 1 atau slack bus dan hanya ditempatkan di antara bus 2 dan bus terakhir $N$, yakni: $2<i<N$

2. DG mempunyai faktor daya yang tetap. $P F_{D G}=1$ merupakan DG tipe 1 , jika $0<$ $P F_{D G}<1$, maka merupakan DG tipe 3 .

\section{Metode Penelitian}

Metode yang digunakan dalam penelitian ini adalah:

\subsection{Pemodelan Jaringan Distribusi}

Jaringan distribusi penyulang Nila dimodelkan dengan model bus dan model saluran untuk kebutuhan perhitungan aliran daya. Model bus terdiri dari nomor bus, jenis bus, daya aktif dan daya reaktif beban yang terhubung pada bus. Beban pada setiap bus dianggap seimbang. Model saluran terdiri dari nomor saluran, nomor dari bus-bus dimana saluran terhubung, nilai resistansi dan reaktansi saluran.

\subsection{Perhitungan Kapasitas dan Lokasi Penempatan Optimal Pembangkit Tersebar (DG)}

Proses perhitungan kapasitas dan lokasi penempatan optimal DG pada penyulang Nila dilakukan dengan langkah-langkah berikut ini:

1. Masukkan data-data dari model beban dan model saluran.

2. Bentuk matriks $B I B C$ dan matriks $B C B V$.

3. Seting semua tegangan awal semua bus sama dengan 1 dan iterasi $k=1$.

4. Hitung nilai arus injeksi dari setiap bus, arus setiap saluran dan tegangan setiap bus. Bila perbedaan nilai tegangan $\mid V_{i}^{k+1}-$ $V_{i}{ }^{k} \mid<$ nilai toleransi, maka lanjutkan ke langkah selanjutnya. Jika tidak, lakukan ulang langkah 4 dan iterasi $k=k+1$.

5. Hitung nilai indeks stabilitas tegangan VSI.

6. Tentukan tipe DG yang akan digunakan.

7. Menghitung nilai-nilai $\alpha_{i j}, \beta_{i j}, X_{i}$ dan $Y_{i}$.

8. Menghitung rugi-rugi daya aktif untuk kasus dasar sebelum pemasangan DG.

9. Menghitung kapasitas optimal DG untuk setiap bus.

10. Mencari lokasi optimal penempatan DG dengan rugi-rugi daya aktif total yang paling minimum.

11. Menghitung injeksi daya aktif dan daya reaktif setiap bus setelah penempatan DG.
12. Seting tegangan awal setiap bus sama dengan 1 dan iterasi $k=1$.

13. Menghitung nilai arus setiap saluran dan tegangan setiap bus setelah penempatan DG pada bus yang dipilih. Bila perbedaan nilai tegangan $\left|V_{i}^{k+1}-V_{i}^{k}\right|<$ nilai toleransi, maka lanjutkan ke langkah selanjutnya. Jika tidak, lakukan ulang langkah 13 dan iterasi $k=k+1$.

14. Menghitung indeks stabilitas tegangan VSI setelah penempatan DG.

15. Menghitung nilai $\alpha_{i j}, \beta_{i j}, X_{i}$ dan $Y_{i}$ setelah penempatan DG.

16. Menghitung rugi-rugi daya setelah penempatan DG.

Perhitungan untuk tipe DG yang berbeda dimulai dengan langkah 6 .

\section{Hasil dan Pembahasan}

\subsection{Kasus IEEE 30 bus}

Studi kasus IEEE 30 bus yang digunakan mempunyai beban dengan faktor daya 0,85 yang terhubung pada setiap bus. DG yang ditempatkan adalah DG tipe 3 dengan faktor daya 0,82 . Hasil perhitungan aliran daya menunjukkan beban daya aktif dan beban daya reaktif total masing-masing sebesar $3715 \mathrm{~kW}$ dan $2295 \mathrm{kVAR}$ dengan rugi-rugi daya aktif total sebesar $211,3 \mathrm{~kW}$. Nilai tegangan dan indeks stabilitas tegangan paling minimum terdapat pada bus 18 yang besarnya masingmasing adalah 0,9036 pu dan 0,6686 .

Hasil pengujian yang diperoleh dengan menempatkan DG tipe 3 pada setiap bus ditunjukkan pada gambar 1 dan rugi-rugi daya aktif total yang dihasilkan untuk setiap bus ditunjukkan pada gambar 2 .

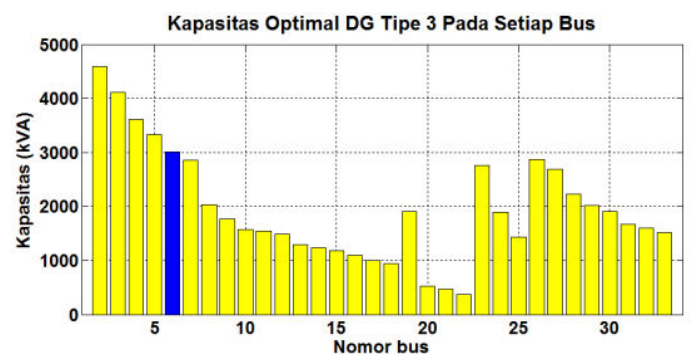

Gambar 1. Kapasitas optimal DG tipe 3 pada setiap bus.

Kapasitas paling optimal DG tipe 3 adalah 3016,43 kVA yang ditempatkan pada bus 6 dengan rugi-rugi daya aktif total sebesar 74,93 
kW. Hasil pengujian yang diperoleh menunjukkan kesesuaian dengan hasil yang diperoleh Hung dkk. yang menggunakan DG tipe 3 dengan faktor daya yang sama.

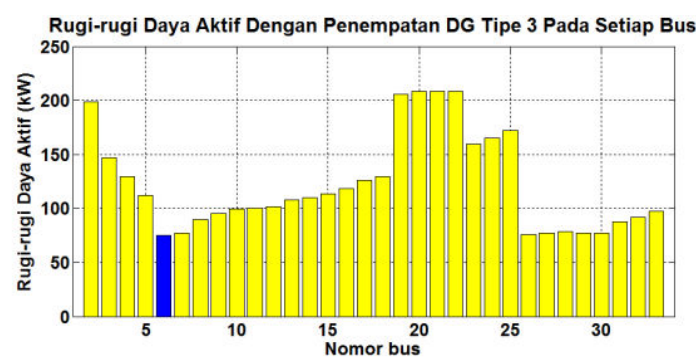

Gambar 2. Rugi-rugi daya aktif total dengan penempatan DG tipe 3 dengan kapasitas optimal pada setiap bus.

Perbandingan profil tegangan dan indeks stabilitas tegangan tanpa dan dengan penempatan DG tipe 3 dengan kapasitas 3016,43 kVA pada bus 6 masing-masing ditunjukkan pada gambar 3 dan gambar 4 . Tegangan dan indeks stabilitas tegangan paling minimum terdapat pada bus 18 yang besarnya masingmasing adalah 0,9546 pu dan 0,8323 .

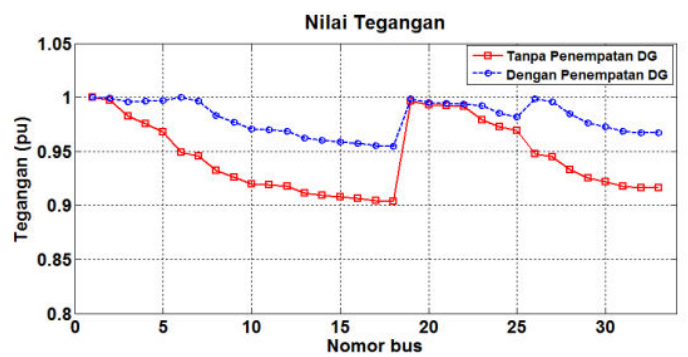

Gambar 3. Perbandingan profil tegangan bus tanpa dan dengan penempatan DG tipe 3 .

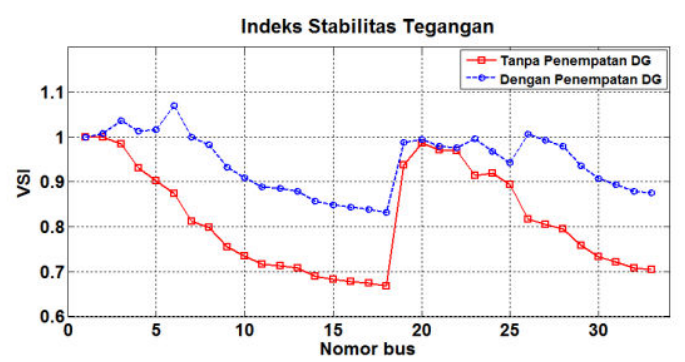

Gambar 4. Perbandingan indeks stabilitas tegangan bus tanpa dan dengan penempatan DG tipe 3.

\subsection{Kasus Penyulang Nila}

Penyulang Nila terdiri dari 111 bus dan 110 saluran. Diagram satu garis dari jaringan distribusi penyulang Nila ditunjukkan pada gambar 5 .

Hasil perhitungan aliran daya untuk penyulang Nila menunjukkan beban daya aktif total adalah $4567 \mathrm{~kW}$ dan beban daya reaktif total adalah $2849 \mathrm{kVAR}$. Rugi-rugi daya aktif total adalah $367 \mathrm{~kW}$. Nilai tegangan dan indeks stabilitas tegangan paling minimum terdapat pada bus 72 yang besarnya masing-masing adalah 0,8741 pu dan 0,5842 .

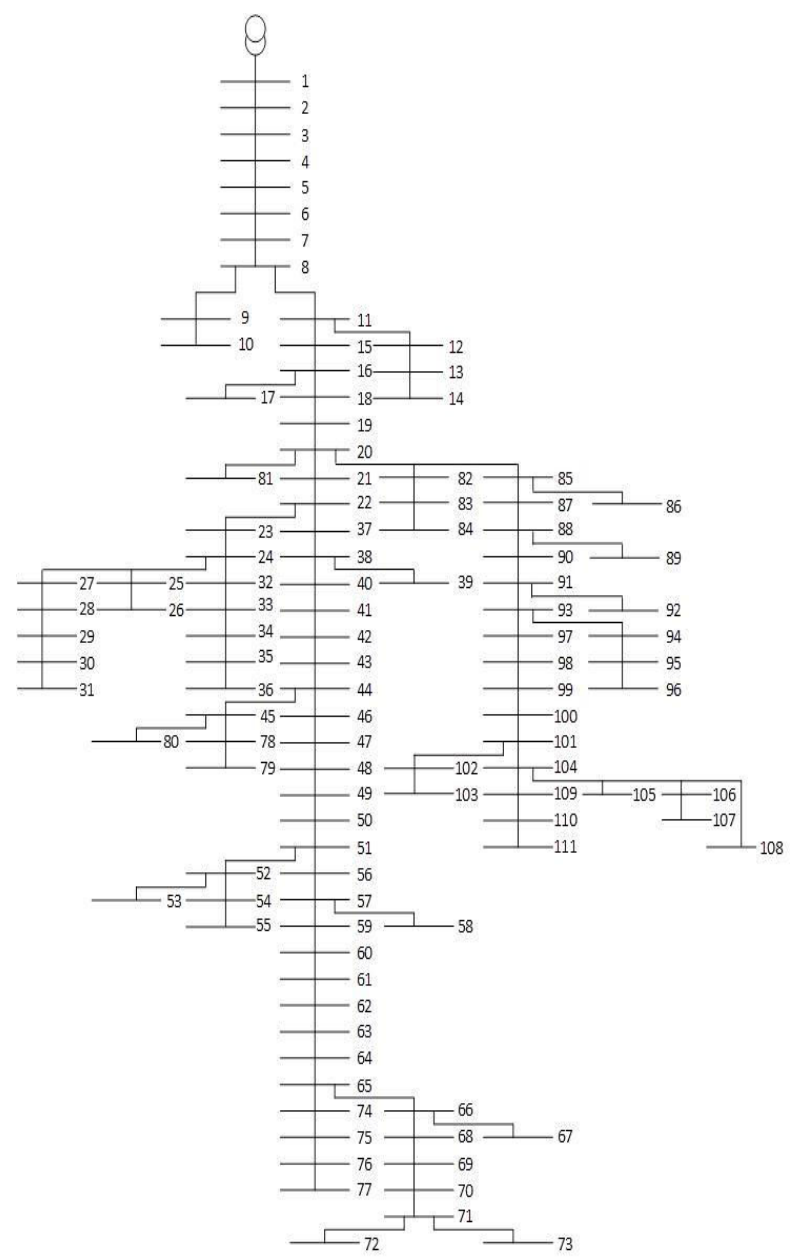

Gambar 5. Diagram Satu Garis Penyulang Nila

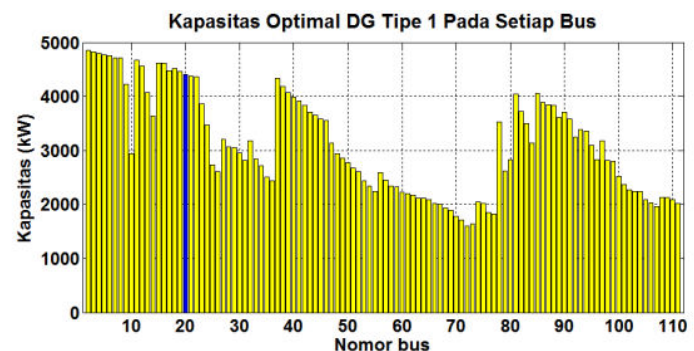

Gambar 6. Kapasitas optimal DG tipe 1 pada setiap bus. 


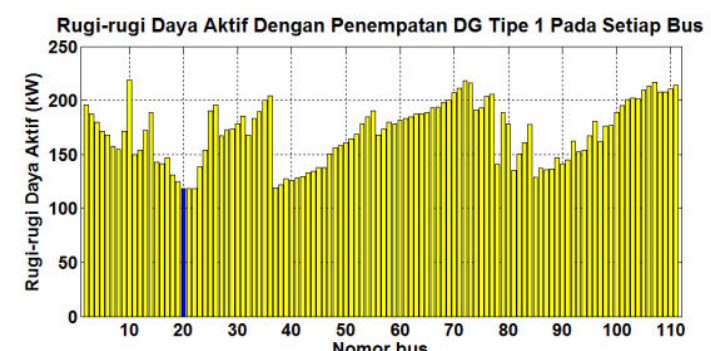

Gambar 7. Rugi-rugi daya aktif total dengan penempatan DG tipe 1 dengan kapasitas optimal pada setiap bus.

Hasil pengujian dengan menempatkan DG tipe 1 pada penyulang Nila, diperoleh kapasitas optimal DG untuk setiap bus, seperti ditunjukkan pada gambar 6 . Rugi-rugi daya aktif total yang dihasilkan dengan penempatan DG tipe 1 dengan kapasitas optimal yang diperoleh untuk setiap bus ditunjukkan pada gambar 7 .

Kapasitas DG tipe 1 yang paling optimal adalah sebesar 4406,92 $\mathrm{kW}$ yang ditempatkan pada bus 20. Penempatan DG tipe 1 dengan kapasitas dan lokasi paling optimal ini menghasilkan rugi-rugi daya aktif total sebesar $123,8 \mathrm{~kW}$. Tegangan minimum dan indeks stabilitas tegangan minimum terdapat pada bus 72 dengan nilai masing-masing adalah $0,9252 \mathrm{pu}$ dan 0,7333 .

Perbandingan profil tegangan tanpa dan dengan penempatan DG tipe 1 dengan kapasitas $4406,92 \mathrm{~kW}$ pada bus 20 ditunjukkan pada gambar 4.

Perbandingan indeks stabilitas tegangan setiap bus tanpa dan dengan penempatan DG tipe 1 dengan kapasitas $4406,92 \mathrm{~kW}$ pada bus 20 ditunjukkan pada gambar 5 .

Penempatan DG tipe 1 dengan kapasitas paling optimal menghasilkan pengurangan rugirugi daya aktif total sebesar $243,2 \mathrm{~kW}$ atau sebesar $66,23 \%$.

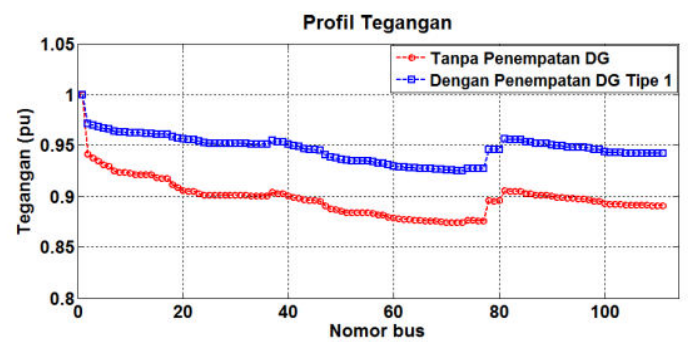

Gambar 4. Perbandingan profil tegangan bus tanpa dan dengan penempatan DG tipe 1 .

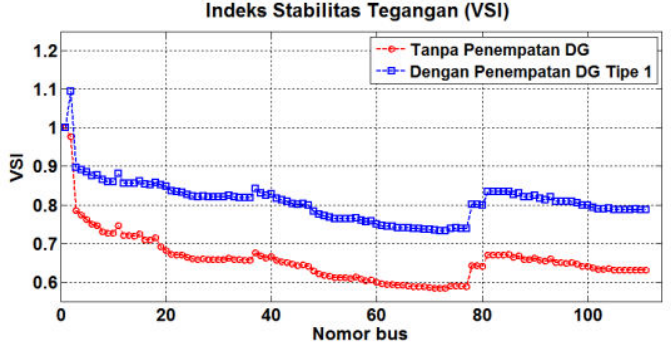

Gambar 5. Perbandingan indeks stabilitas tegangan bus tanpa dan dengan penempatan DG tipe 1.

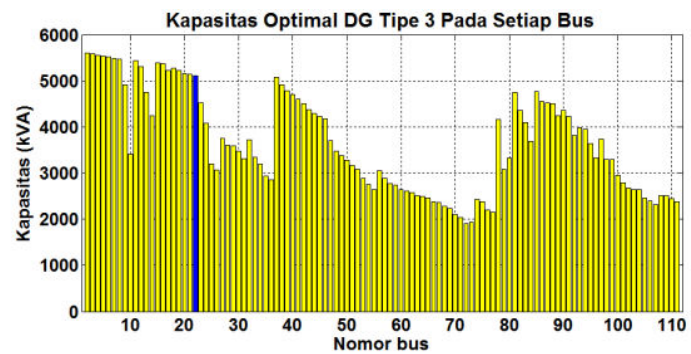

Gambar 6. Kapasitas optimal DG tipe 3 pada setiap bus.

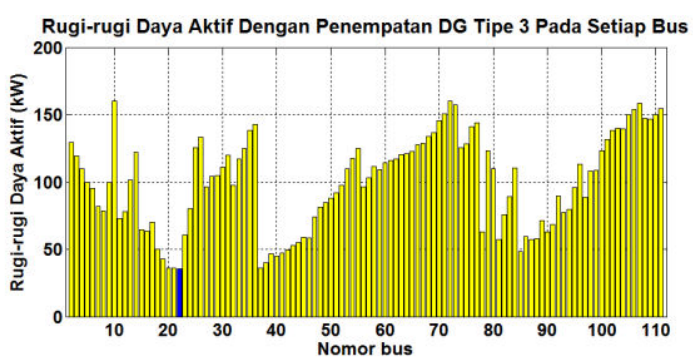

Gambar 7. Rugi-rugi daya aktif total dengan penempatan DG tipe 3 dengan kapasitas optimal pada setiap bus.

Pengujian dengan menempatkan DG tipe 3 dengan faktor daya 0,8 pada penyulang Nila menghasilkan kapasitas optimal DG pada masing-masing bus, seperti ditunjukkan pada gambar 6. Rugi-rugi daya aktif total yang dihasilkan dengan menempatkan DG tipe 3 dengan kapasitas optimal ditunjukkan pada gambar 7.

Kapasitas dan lokasi paling optimal untuk penempatan DG tipe 3 pada penyulang Nila adalah sebesar 5110,54 kVA dan ditempatkan pada bus 22. Rugi-rugi daya aktif total yang dihasilkan oleh penempatan DG tipe 3 dengan kapasitas dan lokasi yang paling optimal ini adalah sebesar $37.7 \mathrm{~kW}$. Tegangan minimum dan indeks stabilitas tegangan minimum terdapat 
pada bus 72 dengan besar masing-masing adalah 0,9749 pu dan 0,9039 .

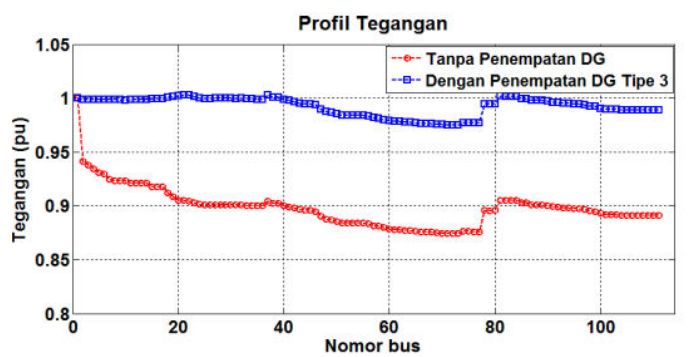

Gambar 8. Perbandingan profil tegangan bus tanpa dan dengan penempatan DG tipe 3 .

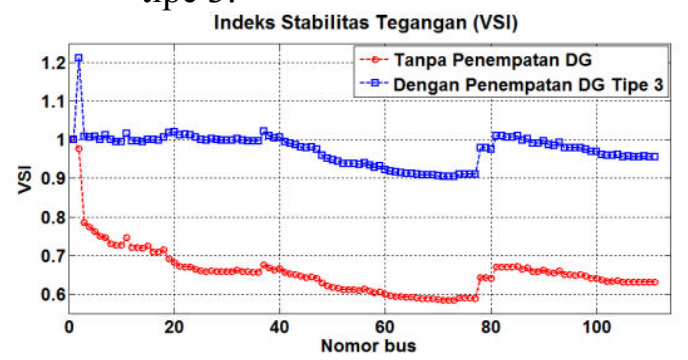

Gambar 9. Perbandingan indeks stabilitas tegangan bus tanpa dan dengan penempatan DG tipe 3.

Perbandingan profil tegangan dan indeks stabilitas tegangan tanpa dan dengan penempatan DG tipe 3 dengan kapasitas dan lokasi paling optimal masing-masing ditunjukkan pada gambar 8 dan gambar 9 .

Pengurangan rugi-rugi yang dihasilkan oleh penempatan DG tipe 3 dengan kapasitas 5110,54 kVA dan ditempatkan pada bus 22 adalah sebesar 333,3 kW atau sebesar 90,82\%.

Hasil pengujian penempatan DG dengan tipe yang berbeda menunjukkan bahwa penempatan DG tipe 3 relatif lebih mengurangi rugi-rugi daya aktif total, memperbaiki profil tegangan setiap bus dan meningkatkan indeks stabilitas tegangan setiap bus di penyulang Nila dibandingkan penempatan DG tipe 1. Namun kapasitas optimal DG tipe 3 yang digunakan relatif lebih besar dibandingkan kapasitas optimal DG tipe 1. Kapasitas paling optimal DG tipe 1 dan DG tipe 3 yang diperoleh mendekati besar beban yang terdapat pada penyulang Nila.

Bila kapasitas DG yang akan ditempatkan menjadi perhatian, maka metode ini juga memberikan alternatif besar kapasitas optimal dari setiap tipe DG dan lokasi optimal penempatannya pada setiap bus di jaringan distribusi. Secara praktis, penempatan DG dengan kapasitas yang besarnya hampir mendekati besar beban total menimbulkan masalah ekonomis dan tidak andal, terutama jika menggunakan DG tipe 1, namun hasil pengujian menunjukkan bahwa dengan menempatkan DG dengan kapasitas terkecil, pengurangan rugi-rugi daya aktif tidak terlalu signifikan.

Metode analisis yang digunakan tidak mengoptimalkan nilai tegangan dalam rentang batas tertentu, yakni antara 0,95 sampai dengan 1,05, dan juga tidak menetapkan batas kapasitas dari DG. Namun lebih mengutamakan perhitungan kapasitas DG pada setiap bus yang menghasilkan rugi-rugi daya aktif yang paling minimum sesuai persamaan 20. Nilai tegangan dan indeks stabilitas tegangan dihitung setelah diperoleh nilai kapasitas DG dan lokasi penempatannya.

\section{Kesimpulan}

1. Metode yang digunakan dapat menentukan kapasitas dan lokasi penempatan optimal dari DG, baik DG tipe 1 dan DG tipe 3, untuk mengurangi rugi-rugi daya aktif total secara optimal, sekaligus memperbaiki profil tegangan setiap bus dan meningkatkan indeks stabilitas tegangan setiap bus pada penyulang Nila di Gardu Induk Natar.

2. Penempatan DG tipe 3 dengan kapasitas dan lokasi optimal relatif lebih mengurangi rugirugi daya aktif total, memperbaiki profil tegangan dan meningkatkan indeks stabilitas tegangan di setiap bus, namun dengan kapasitas optimal yang relatif lebih besar dibandingkan dengan kapasitas optimal DG tipe 1 yang akan ditempatkan.

\section{Daftar Pustaka}

[1] E. Fitrianto dan R. Nazir, "Efek Pengintegrasian Pembangkit Listrik Tersebar Pada Jaringan Distribusi Radial Terhadap Perosotan Tegangan," Jurnal Nasional Teknik Elektro, vol.5, no.1, Maret 2016

[2] Syafii, et al, "Analisa Pengaruh Integrasi Pembangkit Tersebar Dalam Sistem Komposit," Jurnal Nasional Teknik Elektro, vol.3, no.1, Maret 2014.

[3] S. Yunus dan I. Ismail, "Studi Penempatan dan Kapasitas Pembangkit Tersebar Terhadap Profil Tegangan dan Rugi Saluran Pada Saluran Marapalam," 
Jurnal Nasional Teknik Elektro, vol.7, no.1, Maret 2018.

[4] K. Mahesh, et al., "Advanced Pareto Front Non-Dominated Sorting MultiObjective Particle Swarm Optimization for Optimal Placement and Sizing of Distributed Generation," Energies, vol. 9, no. 982, 2016.

[5] N. Mohandas, et al, "Optimal Location and Sizing of Real Power DG Units to Improve the Voltage Stability in the Distribution System Using ABC Algorithm United with Chaos," Electrical Power and Energy Systems, vol.66, pp.41-52, 2015.

[6] A.M. Imran and M. Kowsalya, "Optimal Size and Sitting of Multiple Distributed Generators in Distribution Systems Using Bacterial Foraging Optimization," Swarm Evolutionary Computations, vol.15, pp. 58-65, 2014.

[7] D.Q. Hung, et al, "Analytical Expressions for DG Allocation in Primary Distribution Networks," IEEE Transactions on Energy Conversion, vol. 25, no. 3, September 2010.

[8] M.A. Kashem, et al, "A Novel Method for Loss Minimization in Distribution Networks," Proceeding International Conference Electrical Utility Deregulation Restructure Power Technology, Apr. 2000, pp.251-256.

[9] D. B. Santoso, et al, "Algoritma Aliran Daya dengan Metode Backward /Forward Sweep pada Sistem Distribusi Radial," CITEE 2017, hal. 78-82.
[10] S. Kansal, et al, "Optimal Placement of Different Types of DG Sources in Distribution Networks," International Journal of Electrical and Power Energy Systems, vol.53, pp.752-760, 2013.

[11] M. Chakravorty and D. Das, "Voltage Stability Analysis of Radial Distribution Networks," Electrical Power and Energy Systems, vol.23, pp.129-135, 2001.

\section{Biodata Penulis}

Awansah, menyelesaikan pendidikan S1 di Jurusan Teknik Elektro Universitas Lampung tahun 2018 dengan bidang riset optimisasi sistem tenaga.

Osea Zebua, menyelesaikan pendidikan S1 di Jurusan Teknik Elektro Universitas Sumatera Utara tahun 1995 dan pendidikan S2 di Jurusan Teknik Elektro Universitas Gadjah Mada tahun 2001. Pekerjaan sekarang adalah staf pengajar di Jurusan Teknik Elektro Universitas Lampung dengan bidang riset optimisasi sistem tenaga, stabilitas sistem tenaga dan operasi sistem tenaga.

Herri Gusmedi, menyelesaikan pendidikan S1 di Jurusan Teknik Elektro Universitas Sriwijaya tahun 1996 dan pendidikan S2 di Jurusan Teknik Elektro Institut Teknologi Bandung tahun 2001. Pekerjaan sekarang adalah staf pengajar di Jurusan Teknik Elektro Universitas Lampung dengan bidang riset operasi ekonomis sistem tenaga. 